\title{
Implementing Photovoice in Teaching Speaking to the Tenth Grade Students of SMA (SLUA) Saraswati 1 Denpasar
}

\author{
I Gusti Ngurah Bagus Yoga Widiadnya \\ English Literature Department, Faculty of English Literature, Technology Indonesia University, Indonesia \\ yogawidiadnya16@gmail.com \\ *Corresponding Author \\ Whatsapp Number [085893071459]
}

How to Cite : Widiadnya, I., G., N., B., Y. (2019). Implementing Photovoice in Teaching Speaking to the Tenth Grade Students of SMA (SLUA) Saraswati 1 Denpasarl. International Journal for Educational and Vocational Studies, 1 (7), 676-680

\section{ARTICLE HISTORY}

Received: 12 August 2019

Revised: 11 September 2019

Accepted: 20 October 2019

\section{KEYWORDS}

Speaking Skill;

Photovoice Technique;

\begin{abstract}
This classroom action study dealt with implementing photovoice in teaching speaking to the tenth grade students of SMA (SLUA) Saraswati 1 Denpasar. The purpose of study the student could explain about a picture that showed in the slide show orally. The study have been stated as the following: speaking skill at the tenth grade students of SMA (SLUA) Saraswati 1 Denpasar can be improved through photovoice. This study was conducted in X IPA class that consisted of 36 females and 13 males. These subjects were chosen because faced by the fact that the subjects under study still low in speaking English and lack of confident. It was proved that the mean score of pre-test was 59.18. To enhance the improvement of their speaking skill, the researcher tried to apply photovoice technique. The researcher conducted Cycle I and the results of the data analysis of the reflection were 70.81. Then, the researcher continued the research by conducting the cycle II and the result of the data analysis of reflections in cycle II were 81.02. The finding showed that there was improvement of the students' scores after the implementing of photovoice technique. In addition, the results of the questionnaire showed that option A was $72.47 \%$, option B was $20.70 \%$, option $C$ was $6.81 \%$, and option D was $0 \%$. From the result of the study, it could be concluded that photovoice technique could improve speaking skill of the tenth grade students of SMA (SLUA) Saraswati 1 Denpasar.
\end{abstract}

This is an open access article under the CC-BY-SA license.

\section{INTRODUCTION}

Speaking is a branch of oral communication. In oral communication, speaking can be included as productive skill which is effective and efficient be a way to transfer information from the speaker to the listener in order to express their ideas, event and experiences in certain time, place and situation. Boonkit, (2010) stated that as English is universally used as a means of communication, especially in the internet world, English speaking skills should be developed along with the other skills so that these integrated skills will enhance communication achievement both with native speakers. Speaking is the active use of language to express meaning, andfor young learners, the spoken language is the medium through which a new language is encountered, understood, practiced, and learnt (Hosni, 2014). Christhoper Turk (2000:3) argue that a first stage in building up the confidence to speak is to think about the job of speaking, what tools you will use, and what effects you aim to achieve. Speaking skill in English is students' skill for delivering or sending his or her opinion to another people through spoken; however, speaking skill is difficult to develop if it is not practiced very often and can be done by student in the class. The purpose of the practiced is for making fluency speaking skills of the student, to repair the grammatical in English. Through practice and comprehension activities the learner can internalize some vocabulary and some grammatical structures, which will help the learner to understand more in stage two, when she or she knows enough to actually converse in a simple way (Bhasir, 2011).

According to Brown (2001:322) the interaction between this two modes of performance apply especially strongly to conversation, the most popular discourse category in the profession. In the classroom, even relatively unidirectional types of spoken language input (speeches, lectures, etc.) are often follow by various forms of oral production on the part 
of students. According to Oradee (2012) in foreign language teaching and learning, ability to speak is the most essential skill since it is the basic for communication. Teachers have a responsibility to prepare the students as much as possible to be able to speak in English in the real world outside the classroom (Bahadorfar, 2014; Fitriani et al., 2019; Lubis et al., 2019).

Nowadays, improving students' communicative skill is the goal of teaching speaking because the student can express themselves and know how to use language well. Teachers agree nowadays, student learn to speak foreign language by doing interaction directly. It makes the student should master several components of speaking there are comprehension, vocabulary, pronunciation, grammar and fluency. In the real situation in teaching learning process, teacher cannot escape from reality. It occurs because there are some problems faced by the teacher and the student. The teacher cannot make student pay attention, make the student lack of creativity in making interactive speaking topics, and engagement in whole teaching learning process. So, it is importance for English teachers to find effective techniques to help enhance students' speaking skill, among other English skills they also need to develop (Janudom, 2009; Mustofa et al., 2019; Mukarromah et al.,2019). According to Krebt, (2017) English teachers should adapt different techniques with the aim of improving learning the speaking skill in the classroom. Thus, in this research the researcher wants to adapt photovoice technique to improve students speaking skill. According to Wang, (1997) Photovoice technique has three main goals: (1) To enable students to record and reflect their community's strength and concerns, (2) To promote critical dialogue and knowledge about important community issue through large and small group discussion of photographs, and (3) to share information or issue that happen in our live through a photo. According to Gavin (2003) she stated that Photovoice aims to enable students to speak up about their live or something through images and word. Photovoice method incorporates fun, creativity and collaboration, in a way that encourages participation from community members (Green, 2009).

The research problem of this study is built in the form of the following questions: to what extent is the effectiveness of photovoice technique in teaching speaking skill of the tenth grade students of SMA (SLUA) Saraswati 1 Denpasar. Finding answers to this research is the most important goal of research studies. The study of this research to figure out to what extent is the effectiveness of photovoice technique in teaching speaking skill of the tenth grade student SMA (SLUA) Saraswati Denpasar. The limitation of the present study is actually based on the complexity and broadness of the problem discussed. Speaking as a productive skill, it is important to teach speaking skill to improve student's speaking and the students has to practice it every day because as we know that practice makes our speaking improve. Accordingly, this study will be limited on implementation of Photovoice as a technique to increase students' speaking skills.

\section{METHODS}

The research design that used in the presents study was classroom action research which all of the process was take place in the classroom. The teaching and learning process were divided into two cycles which each cycles consisted of one session. Each sessions consisted of four interrelate activities, namely: planning $(\mathrm{P})$, action $(\mathrm{A})$, observation $(\mathrm{O})$, and reflection $(\mathrm{R})$. The study on the first cycle was started by administrating Initial Reflection (IR) to know pre-existing of the students' speaking skill. The second cycle that started from the Revised Planning (RP) to perform if the first cycle showed increased low or students scored below from standard Classroom Action Research (CAR) was used for the study to improve students speaking skill. Classroom Action Research was an effective media in improving the quality of English teachers' performance in instruction as well as students' achievement in learning English in classroom.

The research instruments were tools which were used by the researcher to collect the required data. namely: student's speaking test and questionnaire which were concisely displayed below: (1) Student's Speaking Test, this individual test conducted to find student's ability in speaking. Pre-test was conducted to find out the initial problems faced by students and to measure the existing linguistic knowledge in speaking skill. Post-test was conducted to measure whether any change was significantly made after the treatment. The teacher scored the student's performance of speaking skill in front of the class by using the rating scale $5-10$. The score qualifications concerned with pronounciation, fluency, vocabulary, grammar. (2) Questionnaire, subjective answers were gathered to find out the student's problems in responding towards the action or condition given. This was also used to support the reflection components. The questionnaire was constructed in the form of multiple choices on the basic of rating score 0-3. Students got 3 score for A answer, 2 score for $\mathrm{B}$ answer, 1 score for $\mathrm{C}$ answer, and 0 score for $\mathrm{D}$ answer. To avoid confusion, the questionnaire was written in Bahasa Indonesia.

The study dealt with research questions: to what extent can the speaking skill of the seventh grade student SMA (SLUA) Saraswati 1 Denpasar be improved through photovoice? There were some research instruments that were used by the researcher in conducting a research, those were speaking oral test, questionnaires. The most valuable data collected from research instrument by giving IR (Initial Reflection) and post-test, and some additional questionnaire data, and then the data was calculated through mean that consisted of the average score of students's achievement in speaking test, the sum of total score divided by the number of students's data analysis by using formula. Furthermore, each item percentage of the questionnaire would be simply counted by summing up all 
of the subjects' answer in each item.

\section{RESULTS AND DISCUSSION}

The data collected from the tenth grade students of SMA (SLUA) Saraswati 1 Denpasar, and the data were gathered through pre-cycle, cycle I, and Cycle II. The researcher made up the research in two cycles to find a very significant improvement of the students's ability on speaking skill through photovoice. The pre-test in speaking was administered to the subjects under study to collect their pre-existing ability in speaking skill. Furthermore, post-test was administered at the end of each cycle. The qualitative findings were obtained from questionnaire carried out after cycle I was completed. It showed the response of the subjects under study towads photovoice to improve speaking skill.

\subsection{Pree-Cycle}

The first step to take data from tenth grade students of class science one by doing the pre-cycle. The researcher took and joined the speaking class and observed the initial condition and students' activity in the classroom to identify their problem. The researcher found that many students have difficulties in speaking, that is because students felt shy and afraid; furthermore, they did not like English lesson especially in speaking English. Some of students had mispronunciation and incorrect grammar in their speaking. In addition, the student had little vocabulary. It makes the students were lack of confidence in speaking English. The students make a group and described an animal about Paradise Bird's photo that showed in the projector. The purpose of giving pre-test was to know the initial problems faced by the students and to measure the student's ability at first. It was done before implementing the classroom action research. The subject were 49 students which was consisted of 36 females and 13 males. After analyzing the students action, it was found that the students' speaking skill on pre-test was 59.18 and it was recognize " fairly satisfactory ". The higher score was 70, it were only 13 students, that means only $26.53 \%$ of the students' enthusiastic to English speaking. There were also 19 students got 60 , and there were 17 students got 50 .

\subsection{Cycle I}

In the cycle I it was followed by all the students of tenth grade science one class. The researcher applied photovoice technique to support the student's activity in expressing, asking and giving the information as a real life situation. Before begining the presentation the researcher gave an explanation about descriptive text and generic structure of descriptive text. After explaining descriptive text, the researcher gave the students example of descriptive text orally with the topic of describing someone. For the first, the researcher described about Sule's photo orally to make them more focus, and then gave explained some expression also an example to make a stress or good intonation by following what the researcher said. After that, the researcher devided the class into a several group which was consisted of each six students. The researcher choose eight students as a model to described by each group, one model for one group. After that the leaders of the group took a photo of the model to be described later. The topic of first post-test in this cycle was about describing someone. The researcher conducted test in the form of short description in pair, and in this cycle I only 13 students could reach the standard minimum score (KKM), that means only $26.53 \%$ of the students showed their enthusiatic to learn about speaking skill. The additional supporting data were collected by means of administering questionnaire by the end of the cycle I to the subject under study. The data obtained from the questionnaire should be computed and discussed in the light of the present class action study. The result of the questionnaire was item A was $72.47 \%$ strongly agreed, item B was $20.70 \%$ agreed, item $\mathrm{C}$ was $6.81 \%$ did not have opinion, and item $\mathrm{D}$ was $0 \%$ disagreed.

\subsection{Cycle II}

The second sessions applied the same activities, but with the different way to explain the expression to make the students more focus to the material. The new topic used in this session is about " Describing Place ", by giving the description and told the students a little bit about the characteristic in that places, began with the politeness words, how to speak to the teacher or friend while the researcher using some gestures to act like the teacher who met with the student and then asked the students to follow the sentence of description quickly, to make them memorize the material. The next activity was also the same as the previous activity, the students described the photo about place in the front of the class. The rule was also the same like before, after explaining the material, the researcher devided the students in some groups, to make a short description about place. In this session the activeness of the students increased and 41 students could reach the standard minimum score (KKM), after the treatment in each cycle apllied. That means $83.67 \%$ showed their enthusiastic about English speaking, and absolutely they could remember the sentences well, and to measure the student's acievement in this cycle. The findings of the present clasroom action study believed that learning speaking through photovoice was effective and gave significant improvement to the students' speaking skill. However, in relationship to the objective of this presents study, these findings could not be generalized to all of the tenth grade students within the same school. This was due to the fact that during the undertaking of this study, they were some compounding variables, which were not simply controlled. Therefore, these research findings were apllicable to the tenth science one grade students of SMA (SLUA) Saraswati 1 Denpasar.

The data analysis above which was the establishment of the findings of the present classroom action study presented that the mean score of the IR or pre-test score 
(X0) by the subjects under study in speaking through photovoice pointed out of mean score of 59.18. The mean score clearly showed that the ability of the subject under study was relatively "fairly satisfactory" in the level of mastery of speaking rubric. The result of the data analysis of the reflection score in cycle I showed increasing the mean score of 70.81. It was higher than the result of pre-test. The gap between the mean scores of pre-test and cycle I was 11.63 this grand mean score of cycle I showed the improvement of student's ability in English speaking through photovoice. In the cycle II, which was the treatment was more intensive in order of weakness of the students had been known. The result of the data anaysis of reflection or post-test in cycle II was that the mean score was 81.02 . The different between mean score in cycle I and II was 10.21. It showed that the student's speaking ability improved after the researcher applied the photovoice to the students. This was due to the fact that cycle II was revised version of cycle I, which was more interesting and interactive. Furthermore, it made the students interested in studying English through photovoice.

Additionally, the development of the subjects under the study was also followed by the subjects' response in learning speaking skill trough photovoice. The comparative percentage figure of total response of the questionnaire for item $\mathrm{A}=72.47 \%$ strongly agreed, $\mathrm{B}=20.70 \%$ agreed, $\mathrm{C}=$ $6.81 \%$ did not have opinion and $\mathrm{D}=0 \%$ disagreed. Furthermore, $72.47 \%$ of the students absolutely liked the technique that applied, and it was confirmed that the subjects' learning behaviour changed positively in attitude and motivation. This also indicated that teaching speaking through photovoice could make active participation and showed each cycle comparatively much bigger than the mean of pre-test score before the treatment applied.

\section{CONCLUSION}

The present classroom action study was conducted to help the students improve and develop their ability in speaking skill. Based on the findings and the discussion presented in chapter IV, it could be concluded that the use of photovoice technique could improve the speaking skill of the tenth grade stdents of SMA (SLUA) Saraswati 1 Denpasar. It can be seen from the result of this research The mean figure of IR was 59.18, this mean figured clearly pointed out that the speaking skill of tenth grade students of SMA (SLUA) Saraswati 1 Denpasar was considered low. The means of $\mathrm{R}$ score for the cycle I obtained by the subjects under study showed the successed mean figured of 70.81 for XI. The mean of the $R$ scores for cycle II obtained by the subjects under study also showed the increasing of the achievement. The grand mean of the $\mathrm{R}$ scores in cycle II to figured the mean of XII $=81.02$. The resulted of the mean figures progressed and increased significantly. The finding of the present classroom action study convicingly revealed that implementing photovoice in teaching speaking effectively improve and increase the speaking skill of the tenth grade students of SMA (SLUA) Saraswati 1 Denpasar.
The other result also could be seen in the questionnaire result, the scores clearly showed the comparative percentage figures of $72.47 \%, 20.70 \%, 6.81 \%$ and $0 \%$ for the respective total response of the items of questionnaire options A, B, C, and D. These finding significantly proved that the attitudes and the learning motivation of the subjects under study changed and heightened positively.

\section{REFERENCES}

Bahadorfar, M. and Reza O. (2014). Technology In Teaching Speaking Skill. Acme International Journal of Multidisciplinary Research. Volume - II, Issue - IV

Bashir, M., Muhammad A., Ashiq H.D. (2011) Factor Effecting Students' English Speaking Skills. British Journal of Arts and Social Sciences. ISSN: 2046-9578, Vol.2 No.1 (2011)

Boonkit, K. (2010). Enhancing the development of speaking skills for non-native speakers of English. Procedia Social and Behavioral Sciences 2 (2010) 1305-1309

Brown, H. Douglas.(2000, 2001, 2003). Language Assessment Principles and Classroom Practices. San Francisco: State University.

Fitriani, F., Nur, R. H., Bustamin, B., Ali, S. M., \& Nurisman, N. (2019). Improving Students' Descriptive Text Writing by Using Writing in the Here and Now Strategy at the Tenth Grade Students of Vocational High School. International Journal for Educational and Vocational Studies, 1(6), 632-636.

Gavin, M. (2003). Developing Positive Negatives: Youth in the Edges Capture Images of Their Live with Help From Photovoice. University of Cincinnat Vol. 13, No. 2, Collected Papers (2003).

Green, E. and Breet K. (2009). Facilitating Youth Participation in a Context of Forced Migration: A Photovoice Project in Northern Uganda. Journal of Refugee Studies, Volume 22, Issue 4.

Heaton, J. B. (1989). Writing and Speaking English Test. British Library Cataloguing.

Hosni, S. A. (2014). Speaking Difficulties Encountered by Young EFL Learners. International Journal on Studies in English Language and Literature (IJSELL) Volume 2, Issue 6

Janudom, R. (2009). Drama and Questioning Techniques: Powerful Tools for the Enhancement of Students' Speaking Abilities and Positive Attitudes towards EFL Learning. www.esp-world.info ESP World, Issue 5 (26), Volume 8, 2009

Krebt, D.M. (2017). The Effectiveness of Role Play Techniques in Teaching Speaking for EFL College Students. Journal of Language Teaching and Research, Vol. 8, No. 5, pp. 863-870. 
Lubis, R. R., Irwanto, I., \& Harahap, M. Y. (2019). Increasing Learning Outcomes and Ability Critical Thinking of Students Through Application Problem Based Learning Strategies. International Journal for Educational and Vocational Studies, 1(6).

Mustofa, R. F., Nabiila, A., \& Suharsono, S. (2019). Correlation of Learning Motivation with Self Regulated Learning at SMA Negeri 1 Tasikmalaya City. International Journal for Educational and Vocational Studies, 1(6).

Mukarromah, I., Mudjito, M., \& Purbaningrum, E. (2019). The Effect of Managerial Skills (Conceptual, Human, and Technical) of Headmasters to the Effectiveness of Islamic Senior High Schools in Jombang District. International Journal for Educational and Vocational Studies, 1(6).

Oradee, T. (2012). Developing Speaking Skills Using Three Communicative Activities (Discussion, Problem-Solving, and RolePlaying). International Journal of Social Science and Humanity, Vol. 2, No. 6, November 2012

Palibroda, Beverly with Krieg, Brigette., Murdock, Lisa. and Havelock, Joanne. (2009). A Practical Guide to Photovoice: Sharing Pictures, Telling Stories and Changing Communities. PWHCE or Health Can

Turk, C. (2006). Effective Speaking. British. Cardiff University.

Umami, I., \& Mashari, A. (2019). The Contribution of Teachers' Motivation and Characteristics on The Teachers Performance in Junior High School of Maarif Metro Lampung. IAIN METRO.

Wang, C., and Mary, A.B. (1997). Photovoice: Concept, Methodology, and Use for Participatory Needs Assessment. Sage Journals. Volume: 24 issue: 3 